votaries than ever. On opening, the other day, a book of the curious "Anglo-Israelite" sect, I met with the following passage, written in evident seriousness by a seeker after proofs that the British nation are the Lost Tribes of Israel:- "I am even now acquainted with many words in current use in some parts of the West of England that were in common use by Israel of old, and that I have not found in use in any other country - such as goad, gourd, barm, leaven, comrade, lattice, chambering, flay, score, gallon, cruse, lintel, latchet, girdle, pitcher, platter, glean, \&c., \&c." It takes a little thought to understand the full depth of ignorance of a man who, finding these words in the English Bible, thought they were used by the ancient Israelites. Why I ask you to notice it is that the author of the volume it is printed in says that I00,000 copies of his work have been sold; there is, indeed, no doubt but that this abject nonsense has a far larger circulation than all the rational ethnology published in England. It opens a window by which we can see into the state of education of its readers, who mainly belong to the lower middle class, and whose thousands of schools are as yet unvisited by the University Delegates on the one hand or the Education Department on the other. Even our Public Elementary education, good as it is in many respects, passes some questionable anthropology. Happening to look a few days ago at a Third Standard book on English History, I was surprised to find a picture of a South Sea Islander, tattooed all over, standing to represent the condition of the ancient Britons, who are described as savages. Now this is hardly an appropriate designation for a pastoral and agricultural people, who had a gold coinage, and whose war-chariots even the Roman legionaries found troublesome to deal with.

Having now attempted to support the claims of the problems of human nature to fuller recognition in our system of advanced education, it may be well to observe by way of caution that anthropology, while contributing materials to other sciences, does not dictate the conclusions which each science is to draw from them. It has not a rule of morals, a system of politics, or a doctrine of religion to teach, only a series of facts showing the stages through which each of these has been developed, and with these the counsel that the anthropological way of studying human conduct is to trace its principles along the historical line of their change and progress. Anthropology, though acknowledging degeneration as an important factor in human life, gives no encouragement to pessimist theories of society. The clinging to life by savage and civilised alike is a measure of their judgment that with all its ills it is a substantial good, to be valued and defended. That the tendency of mankind is toward industrial progress need not be proved, for it is not denied. That moral progress is on the same footing rests on the main fact that man obtains the happiness he seeks, not only through his own sensations but by sympathy with the enjoyments of others ; now beings whose interests are thus consonant with the prosperity of those around them are plainly on the road to good rather than evil. At the same time facts constantly presenting themselves in anthropology guard the student from a prejudiced optimism. He has the picture constantly before him of low-cultured but kindly and truthful tribes of favoured climates, into whose midst the march of civilisation is bringing the beginnings of trade and wealth, and with them temptations to selfishness and dishonesty. At every step in the advance towards prosperity he sees, accompanying the growth of knowledge and the raising of the social standard, a series of concomitant evils, the break-up of the old stage, the failure to assimilate the new. Often a dispiriting lesson, this is yet of the highest practical value, for it elucidates what the statesman should be ever striving to learn, how, in the remodelling of institutions, to gain the utmost advantage while minimising the accompanying loss.
To conclude: my explanation of the unsymmetrical way in which I have here put forward the cause of anthropology must be that the necessity of the case compelled me to a certain scrappiness of treatment. For presenting my subject thus in shreds and patches I am tempted to apologise in that well-worn lecturer's jest, the story of the man who had a house to sell and carried about a brick as a specimen. Perhaps, however, there may be more of a moral in this story than is commonly supposed. I cannot help fancying that the flippant Greek who first told it had actually seen something of the kind done in sober earnest. He may have watched some grave Roman going down to the prætor's court carrying a tile in his hands, which in the lawsuit was to be the legal symbol of the house itself, just as a farm would be represented by a sod of its turf, or as one of our Teutonic forefathers, living in a wooden house, would transfer it by handing over a chip from the doorpost. This indeed is the very position in which I find myself placed in undertaking to treat of anthropology in two lectures. Because the whole structure is too extensive and too massive to bring into ccurt, I have been obliged to symbolise it by fragments taken here and there, and can only ask that these be accepted as symbols, placing the edifice they represent under the guardianship of the University of Oxford.

\section{THE ARCTIC METEOROLOGICAL STATION} ON THE LENA

THE last number of the 1zvestia of the East-Siberian branch of the Russian Geographical Society gives further news of the Lena Arctic Meteorological Station, dated October 24, I882. This news was brought by the American officers. Messrs. Garber and Schütze, who left the station on October 25, and reached Yaiutsk on November 29. Mr. Schütze made a sketch of the station, which appeared in the Izvestia, and which we reproduce. The house brought from Yakutsk proved to be comfortable and warm. It has been erected at the Sagastyr arm of the Lena, on Sagastyr Island (in $73^{\circ} 22^{\prime} 30^{\prime \prime} \mathrm{N}$. lat., and $144^{\circ} 14^{\prime} 46^{\prime \prime} \mathrm{E}$. long.) ; the name of this island is very significant : it means "it blows a way." Galleries of planks have been erected behind the house to connect it with four pavilions for instruments. Besides the coal that has been taken from Yakutsk, the station has a good supply of fuel in the driftwood scattered around the station. The Sagastyr arm of the Lena supplies the inhabitants of the station with fresh fish. The health of all the members is satisfactory. Dr. Bunge received a contusion to a rib during the journey, but he is now well, and is besieged by indigenes, who come to him for medical help. Several Tungus families stay at one and two miles' distance from the station, and they are on the best terms with the meteorologists. The temperature is very low and, as there is no snow, the prospects are not very brilliant. The soil is frozen to a great depth, and cracks; the rivers and lakes are covered with a thick sheet of ice, so that the water beneath the ice is shallow, and the fish are in want of air to breathe. The food for the reindeer is frozen. Even at Yakutsk there was but one inch of snow on December 16, and a great inundation is expected for the spring, as well as epidemics, which are said usually to follow inundations.

As to the journey from Bulun to Sagastyr, it was performed not without difficulties. On August 6 a fresh west wind compelled the boats to stop on unfavourable ground, and the wind blowing with increasing force, it soon turned out a strong storm, blowing from north-west on August 9. The boats were thrown aground close by the banks of the river, and filled with water. The waves rolled above their decks. The chief instruments were, however, safe, as they were landed in time. On August I 9 the expedition reached the Ketakh settlement, seven 

miles south of the signal usually drawn on the maps of
the delta of the Lena. Three days later the expedition
began to erect the building and arrange the instruments.

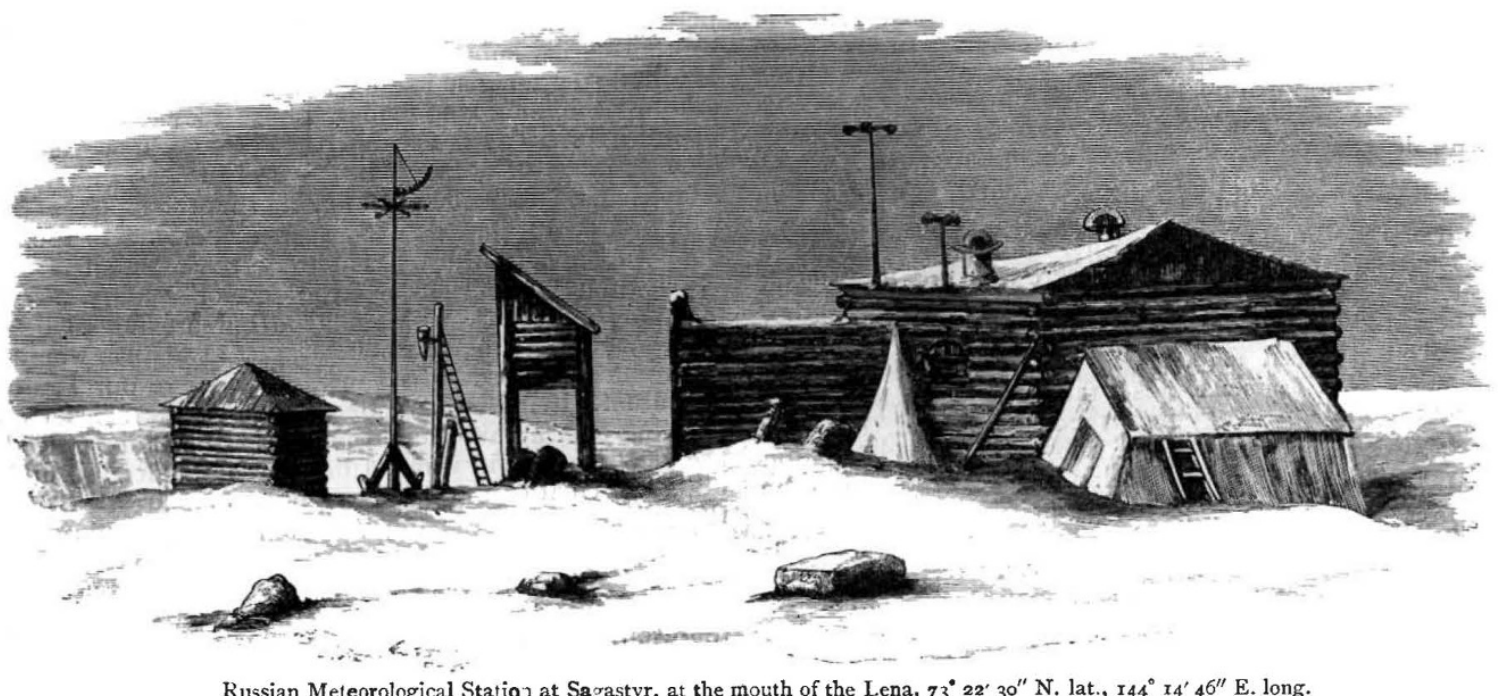

The house of the station is obviously very small; and when looking at Mr. Schütze's sketch of this small building, lost amidst the snow-plain, far from any communica-

\section{THE AURORA BOREALIS}

$\mathrm{A}^{\mathrm{N}}$ MONG the numerous varieties of the aurora borealis or northern light, there is one of particular interest as regards the determination of the origin of this phenomenon. This variety, which was observed and reported upon in 1868 by the members of the Swedish Polar Expedition, takes the form of tiny flames or a phosphorescent luminosity, appearing during the winter months in the Polar regions, around projecting objects, viz. mountain cones and ridges. This phenomenon is so prominent that ore need no: be a scientist to discover it, and it was observed by our well-known philologist, Herr M. A. Castrén, during his journeys in Siberia. Herr Castrén's descriptions of the phenomenon are very minute, and exactly in accordance with its usual appearances, but his observations were, however, not known to me in I868, and it was only on the return of the expedition that I heard of them. The observations made by the Swedish expedition at Spitzbergen led the Finnish Society of Science in I87 I to despatch an expedition, of which I was a member, to Lapland to ascertain if such a phenomenon could not be called forth, or at all events magnified, by mere mechanical appliances. And assuming that the aurora borealis in general, and the variety of the same just mentioned in particular, is caused by electric currents in the atmosphere, an apparatus of the following nature was erected on Luosmavaara, a mountain-top about 520 feet above the surface of the Lake Enare, in Lapland. It consisted of a number of fine points of copper wire laid out in the shape of a wreath two square metres in area, and connected by a circular wire of the same metal. This wreath was attached to a long pole, from the top of which a single copper wire $\left(0^{\circ} 4 \mathrm{~mm}\right.$. in diameter) led to a galvanometer fixed in a room in the Enare vicarage, some two miles distant east, and from the galvanometer another copper wire led to a disk of platina in the earth.

When this circuit was closed, the galvanometer gave a deflexion, although faint. But on the very same night the apparatus was erected, viz. November 22, I871, there atbeared an aurora, which began with a single perpendi- tion with the civilised world, one cannot but admire the devotion of those who have willingly submitted to remain in these inhospitable latitudes for scientific purposes. cular column of light above the top of the Luosmavaara! This column was analysed with the spectroscope, and gave the usual yellow-green line, but whether the column was on or behind the mountain-top could unfortunately not be clearly ascertained. That it, however, had its origin from the apparatus described above appears to me, after the researches were made which I am about to detail, to be beyond a doubt. At the same time, on November 22, 1871, it was observed, when studying the spectrum of the flames which, on that day appeared around the mountain-tops more distinctly than usual, that the characteristic yellow-green line in the spectroscope was returned from nearly every object, as, for instance, the ice of a pond, the roof of a shed, and even, though faintly, from the snow in the immediate vicinity of the observatory. These observations led me to believe that I was within a sphere of electric discharge, whose radius extended considerably around the station.

This interpretation of mine has, however, not been generally accepted by students of the phenomenon, who, on the other hand, have explained the appearance as being an aurora reflected from the earth; but that this theory is erroneous will be clearly demonstrated by the researches detailed below.

In Baron Nordenskjöld's exhaustive investigations of the aurora borealis during the Vega expedition, he states that he was unable to discover this phosphorescent phenomenon which I have observed, and that he had noticed in the spectroscope, in connection with the same, a faint band near the line $\mathrm{D}$; but this has nothing whatever to do with the auroral line. In order, however, to make it clear that I have not confused these two lines, I may state that already in $187 \mathrm{I}$ I observed the absorption-band in question, as will be seen from my work at the time on the aurora borealis and the auroral spectrum. In these researches I determined the wave-length of this line, and as the latter is only apparent in daylight or moonshine, while my observations were without exception made in the dark, it is perfectly clear that this line or band has nothing in common with the auroral one. The two lines are, in fact, of such a different character that they cannot 